\title{
Using Prior Corporate Convictions to Impeach
}

\author{
Steven L. Friedlander †
}

This Comment suggests that courts should allow prior corporate convictions to impeach witnesses at trial in certain circumstances. The author argues that the language and interpretation of Federal Rule of Evidence $609(a)$, dealing with prior individual convictions to impeach, is an inappropriate vehicle for admitting such convictions. He suggests that in the context of corporate convictions, a court must go through a two-step process before admitting prior corporate convictions to impeach. First, the court must assess the prior crime's relevance to the witness. Next, if the crime is relevant, the court must decide whether the probative value of admitting such a conviction outweighs its prejudicial effect. The Comment concludes with a proposal for when courts should admit corporate convictions to impeach, and then provides language for a special evidentiary provision that alleviates the current problems of applying Rule 609(a) to corporate convictions.

In State of Oklahoma v. Allied Materials Corp. ${ }^{1}$ the state sought to introduce evidence of the defendant corporations' prior criminal antitrust convictions $^{2}$ to inpeach the corporate witnesses, and the defendants moved to suppress the evidence. The court denied the defendants' motion to suppress. Without any acconipanyinig rationale, the court allowed the state to introduce the prior convictions to impeach those witnesses who were individually convicted in the previous illegality and those witnesses who were "officers, directors, or inanaging agents" of the convicted corporations. ${ }^{3}$

The court did not perceive any special problems with using corporate convictions to impeach. A corporate conviction holds the corporate

$\dagger$ B.A. 1986, University of California, Berkeley; J.D. 1990, University of California, Berkeley. The author gratefully acknowledges the help of Jim Bayles, Professor Daniel Rodriguez, Ragesh Tangri, Jessica Vapnek, and Michael Page in preparing this unanuscript. Thanks also to Stacey, Ricki, Elizabeth, Joyce, Larry, Harry, and Fay for reading and commenting upon earlier versions.

1. 312 F. Supp. 130 (W.D. Okla. 1968).

2. In reaching its decision the court treated the prior convictions as "separate and apart" from the current antitrust charges. Id. at 133 .

3. Id. The district court, however, clearly limited its decision to adınit prior corporate convictions to impeach only those particular individuals. The judge stated: "I do not believe that a conviction . . . would taint all einployees of a corporation so as to make thein subject to impeachinent by reason of the conviction of their corporate employer." Id. (einphasis added). 
entity, as distinct from the individuals within the corporation, criminally responsible. When the court said that those witnesses in Allied Materials who were individually convicted in the previous illegality could be impeached with their convictions, it was saying nothing new. ${ }^{4}$ The court, however, was in inarkedly different territory when it allowed inpeachinent by previous corporate convictions of persons who were officers, directors, or managing agents. This ruling would allow the prosecution to introduce previous corporate convictions to inpeach witnesses even though under corporate hability principles those individuals could have had no knowledge of - and nothing to do with-the previous illegality. ${ }^{5}$

The merit of using prior corporate convictions to impeach has not previously been analyzed, either by commentators or by courts. ${ }^{6}$ Determining when to use such convictions to impeach an individual requires a inore refined analysis than does deterinining when to use prior individual convictions for the saine purpose.

For exainple, under current law, even the most subordinate employee can bring liability to the corporate entity. ${ }^{7}$ In the context of a large corporation, however, it does not inake inuch sense to use such a conviction, one based on only one person's error, to impeach all other corporate employees at future trials. Should any employees, then, be impeached on the basis of a previous corporate conviction? And if so, which ones? These questions forn only part of the inquiry into using prior corporate convictions to impeach.

The nature of the previous crime is also important to that crime's inpeachment value. Forgetting to file one required report may be an isolated incident that does not reflect upon a company's policy, and would therefore not have impeachment value against a corporation's policymakers. In comparison, when the highest-ranking officials at Ford

4. Impeachment of an individual with evidence of his own previous criminal convictions is a well-accepted practice in both state and federal courts. See, e.g., FED. R. EviD. 609 (allowing admission of some felonies, provided probative value outweighs prejudicial effect, and crimes involving dishonesty or false statement, regardless of pumishment); CAL. EVID. CodE § 788 (West 1960) (allowing admission of some felonies).

5. Furthermore, it would be possible under the court's language to use the previous corporate convictions to impeach officers, directors, and managing agents who were not employed by the corporation at the time of its previous illegality. The court's language required only that witnesses at trial be officers, directors, or managing agents, apparently without regard to their employment status at the time of the previous conviction. Allied Materials, 312 F. Supp. at 133 (court silent on whether witnesses must have been employed by corporation at time of previous corporate conviction).

6. The Supreme Court noted the problem in dicta, but did not consider the impeachment value of the prior conviction apart from bias; nor did the Court take into account the special nature of corporate convictions. United States v. Trenton Potteries Co., 273 U.S. 392, 404-05 (1927) (suggesting that asking whether witness knew his corporate employer had pleaded guilty to a violation of the Sherman Act was not improper if directed to the witness' bias).

7. See infra note 35 and accompanying text. 
Motor Company decided that it would be more economical to produce defective Pintos, Ford's company policy was directly responsible for the accidents and injuries that occurred as a result of this decision. ${ }^{8}$ The nature of the violation has implications for the credibility of at least highlevel officials testifying at future trials.

Federal Rule of Evidence 609 addresses the problein of using prior convictions to impeach a witness. In this Comment, I analyze the rationale behind using prior convictions to impeach, pointing out the inadequacies of the language used in the federal and state evidentiary rules, as exemplified by Federal Rule 609(a), for admittimg prior corporate (as opposed to individual) convictions to impeach. I limit my discussion to Rule 609(a) out of smiphicity; although "state adoptions of Rule 609 vary considerably," both 609(a) and analogous state statutes iguore the special nature and use of prior corporate convictions to impeach. Thus, the comments on how to deal with such convictions are applicable to both contexts.

Rule 609 "regulates the use of prior convictions to mipeach witnesses by suggesting untruthful character or disposition." " Subdivision (a) states the general rule for the admissibility of prior convictions:

For the purpose of attacking the credibility of a witness, evidence that the witness has been convicted of a crime shall be admitted if elicited from the witness or established by public record during cross-examination but only if the crime (1) was punisliable by death or imprisonment in excess of one year under the law under which the witness was convicted, and the court determines that the probative value of admitting this evidence outweighs its prejudicial effect to the defendant, or (2) involved dishonesty or false statement, regardless of the punishment. ${ }^{11}$

Rule 609(a)(1) allows the court discretion to decide whether the probative value of admitting a previous felony ${ }^{12}$ for impeacliment purposes outweighs the prejudicial effect to the defendant. In Green v. Bock Laundry Machine Co., however, the U.S. Supreme Court has construed this discretionary language to apply only in criminal cases, where impeachment could prejudice a criminal defendant. ${ }^{13}$ In a civil trial, any

8. See infra notes 96-103 and accoinpanying text (discussing the Ford case); see also Dowie, Pinto Madness, MOTHER JoNes, Sept.-Oct. 1977, at 18, 21-23 (Ford policymakers emphasized profits over safety when producing Pinto).

9. 3 D. Louisell \& C. Mueller, Federal Evidence $\$ 314$, at 310 (1979).

10. Id. $\S 314$, at 284. The Rule does not apply to using "prior convictions to contradict a witness who denies prior misconduct, or to prove circumstantially such things as knowledge, intent, or identity." Id. $\S 318$, at 343 .

11. FED. R. Evid. 609(a).

12. The Rule uses the congressional definition of a felony: an offense punishable by death or imprisonment in excess of one year. Id. advisory committee's note.

13. Green v. Bock Laundry Mach. Co., 109 S. Ct. 1981, 1990-91, 1993 (1989). This judicial discretion applies to impeachment not only of the criminal defendant himself but also of any witness offered on the defendant's behalf. Id. at $1984 \mathrm{n} .5$. 
witness' prior felony convictions must be admitted, with no balancing of probative value and prejudice. ${ }^{14}$ In addition, the language of Rule 609(a)(2) requires the judge to admit evidence of prior convictions whenever they involve "dishonesty or false statement."15

Subsection (a)(1) refers to the penalty of a previous criminal offense. Thus, it is easy as a preliminary inatter to determine when a previous conviction will be covered by its provisions. ${ }^{16}$ By contrast, (a)(2) refers to the substance of the previous offense, which makes it difficult to determine the crimes to which it refers. ${ }^{17}$ If falsehood or dishonesty is included as one of the elements of the previous conviction, it is clear that the conviction falls within the ambit of (a)(2). ${ }^{18}$ Courts have also looked to the facts underlying particular convictions in deciding whether such convictions fall within (a)(2). ${ }^{19}$ For purposes of this Comment, precision in the definition of which substantive crimes fall within (a)(2) is not as miportant as the fact that some convictions for corporate crime will come under (a)(2), ${ }^{20}$ and that courts must address these situations when they arise.

This Comment will argue that the current application of Rule 609(a) to corporate convictions is inappropriate for several reasons, and

14. Id. at 1993 (holding that Rule 609(a)(1) requires judge to permit impeachment of civil witness with evidence of prior felony convictions regardless of unfair prejudice to witness or party offering testimony). The Court stressed that under Rule 609(a)(1), a judge must consider prejudicial effect only to the defendant. Id. at 1984. The Court held that since this textual limitation applied only to criminal defendants, and was not due to any oversight by the legislature, id. at 1991-92, the general balancing provision of Rule 403 , see infra note 88 , was inapplicable to witnesses in civil cases. Green, 109 S. Ct. at $1992-93$.

15. FED. R. Evid. 609 (a)(2).

16. Note that "it is the possible nature and extent of punishment, rather than the punishment actually imposed upon conviction, which is important for purposes of the Rule." 3 D. LouiselL \& C. MUELLER, supra note $9, \S 316$, at 323 (citation omitted).

For a discussion of how Rule 609(a)(1)'s limitation to felonies punishable only by "death or imprisonment" makes it inadequate to deal with prior felony corporate convictions that do not have "death or imprisonment" as penalties, see infra notes $92-95$ and accompanying text.

17. The House-Senate Conference Committee stated that Subseetion (a)(2) is meant to cover "crimes such as perjury or subornation of perjury, false statement, criminal fraud, embezzlement, or false pretense, or any other offense in the nature of crimen falsi, the commission of which involves some element of deceit, untruthfulness, or falsifieation bearing on the accused's propensity to testify truthfully." H.R. CONF. ReP. No. 1597, 93d Cong., 2d Sess. 9, reprinted in 1974 U.S. CODE Cono. \& ADMIN. NEwS 7098, 7103.

18. 3 D. LOUISELL \& C. MuelleR, supra note 9, § 317, at 339.

19. See id. $\S 317$, at 340 ("if the underlying facts indicate falsehood or dishonesty in the narrow sense of deception," courts may treat such convictions as embraced by 609 (a)(2)); see also United States v. Lipscomb, 702 F.2d 1049, 1066 (D.C. Cir. 1983) (en banc) (finding an implicit congressional understanding "that the court can inquire into the background facts and circumstances if it wants to"), disapproved on other grounds, 469 U.S. 38, 40 n.3 (1984).

20. Examples of substantive crimes that may fall within a(2) include 18 U.S.C. $\S \S 1001$ (false statement), 1005 (bank fraud), 1341 (mail fraud), 1621 (perjury), 1623 (same) (1988); Securities Act of 1933, § 17(a), 15 U.S.C. § 77q (securities fraud) (1988); and Securities Exchange Act of 1934, Rule 10b-5, 15 U.S.C. § 78j (same) (1988). 
that the determination of when impeachment based on prior corporate convictions is appropriate should always remain in the discretion of the court. First, the language of Rule 609(a) itself does not accommodate the use of corporate convictions to impeach. Second, both the Supreme Court's determination in Green of when automatic adımission under (a)(1) is appropriate, and the coinpulsory admission language of (a)(2), are based on considerations relevant to the mipeachment value of prior individual, but not corporate, convictions. Third, in applying Rule 609(a), courts have not taken the more sophisticated two-step approach needed to decide whether to admit prior corporate convictions to impeach. Unlike the one-step approach used for analyzing individual convictions, in which a court simply determines whether impeachment value outweighs prejudicial effect under (a)(1), or whether a crime fits under (a)(2), a court analyzing a prior corporate conviction must also determine whether the conviction is at all relevant to the specific corporate witness.

Part I of this Comment discusses three theories of corporate criminahity, examines the rationale behind corporate convictions, and sets the foundation for estabhishing a link between a corporation's prior conviction and corporate witnesses at trial. The perpetrator of a corporate crime is a fictional entity and is therefore necessarily unable to be a witness at trial. Thus, in order for the prior corporate conviction to be relevant, and therefore admissible ${ }^{21}$ for impeachment, the witness at trial must be linked to the previous illegahty. This Comment discusses in Part II the possible links that can be established between the prior conviction and the corporate witness. Part III points out the inadequacies of Rule 609(a) in handling prior corporate, as opposed to individual, convictions. Part IV analyzes several factors that are important to a court's discretionary decision whether to admit evidence of prior corporate convictions. Finally, in Part V, the Comment concludes with a proposal for when courts should adımit such convictions.

\section{I \\ Corporate Criminal Liability-Practice AND THEORY}

The potential criminal liability of corporate entities has changed substantially simce Lord Holt's observation that "[a] corporation is not indictable, but the particular members of it are."22 Although the earliest cases in the United States for the most part accorded with Lord Holt's

21. "Evidence which is not relevant is not admissible." FED. R. Evid. 402.

22. Case 935. Anonymous, 88 Eng. Rep. 1518 (K.B. 1701); see also 1 W. BLACKstone, COMMENTARIES *476 ("A corporation cannot commit treason, or felony, or other crime in its corporate capacity ... though its members may, in their distinct individual capacities."). 
comment, ${ }^{23}$ the development and expansion of American corporations forced the courts to take action to control corporate criminal activities. Although corporations were legally created entities, they certainly were not fictitious. They had a very real impact on society.

In response to these realities, corporate criminal liability expanded along two lines of authority. The older line of authority, adopted by federal criminal law, borrowed agency principles from civil law. ${ }^{24}$ The newer line of autliority, reflected im the Model Penal Code and adopted by statute im a number of states, is based on a more direct theory of liability that equates corporate action witl the action of top management. ${ }^{25} \mathrm{~A}$ third basis for loldimg a corporation responsible, tliough not a theory on which current corporate criminal liability is based, holds a corporation liable for its deviant "personality."26

\section{A. Respondeat Superior Liability}

The first tlieory of corporate blameworthiness holds a corporation morally responsible for the behavior of each of its agents. This is the theory of respondeat superior, which is based on the idea that when an agent commits a crime witlin tlie scope of employment with the intent to benefit the corporation, the corporation sliould be lield criminally responsible. The corporation hired the agent and stood to benefit from the agent's actions, and should therefore bear the costs the agent imposes on others.

In New York Central \& Hudson River Railroad v. United States, ${ }^{27}$ the Supreme Court attributed criminal intention to a corporation for the first time by applying the theory of respondeat superior, previously confined to the civil realm. By doing so, the Court was able sinultaneously to "embody" tlie corporate form so as to attribute intent to the corporation, ${ }^{28}$ and to overcome the statutory barrier that prevented the corpora-

23. See, e.g., State v. Great Works Milling \& Mfg. Co., 20 Me. 41, 43 (1841) (corporation "can neither commit a crime or misdemeanor, by any positive or affirmative act, or incite others to do so, as a corporation"); $c f$. State v. Morris \& E.R.R., 23 N.J.L. 360, 364 (1852) (although "corporation cannot, from its nature, be guilty of treason, felony, or other crime involving malus animus in its commission," corporation ean be liable for imdictment not requiring corrupt intent).

24. See infra notes 27-39 and accompanying text.

25. See infra notes $40-45$ and accompanying text.

26. See infra notes $46-47$ and accompanying text.

27. 212 U.S. 481 (1909).

28. The conceptual problem of attributing a mental state to the corporation, as opposed to the individuals withm the corporation, remains a subject of substantial debate. See H. BALLANTINE, CORPORATIONS $\S 114$ (rev, ed. 1946) (criticizing reliance upon the analogy of vicarious liability for torts as a principle for finding corporate criminal responsibility); Francis, Criminal Responsibility of the Corporation, 18 ILl. L. REv. 305, 316 (1924) (same); Mueller, Mens Rea and the Corporation, 19 U. PrTr. L. Rev. 21, 38-41 (1957) (criticizing courts for failing to appreciate material differences between the law of corporate criminal liability and tort law). 
tion from being prosecuted for those crimes that could be committed only by human beings.

The defendant railroad company in New York Central was accused of giving illegal rebates to sugar companies im violation of the Elkins Act. $^{29}$ The Elkins Act, which regulated interstate shipment, required that:

[i] $n$ construing and enforcing the provisions of this section the act, omission, or failure of any officer, agent, or other person acting for or employed by any common carrier acting within the scope of his employment shall in every case be also deemed to be the act, omission, or failure of such carrier as well as that of the person. ${ }^{30}$

Rejecting a due process challenge, the Court found the Act constitutional. ${ }^{31}$ So long as the action was done within the scope of the agent's employment and was done to benefit the principal corporation, ${ }^{32}$ the Supreme Court held that, under the doctrine of respondeat superior, a corporation may be criminally responsible as an entity for its agents' actions. $^{33}$

Respondeat superior has remanied the common law rule for imputing criminal hability from corporate employees to the corporate entity. ${ }^{34}$ Corporate criminal responsibility can be based on the acts of any agent of

29. 212 U.S. at 489-91.

30. The Elkins Act, ch. 708, 32 Stat. 847, 847-48 (1903), repealed by Pub. L. No. 95-473, 92 Stat. 1337, 1466-67 (1978).

31. New York Central, 212 U.S. at 496-97.

32. Subsequent courts have held, however, that actnal benefit to the corporation is not determinative. See Old Monastery Co. v. United States, 147 F.2d 905, 908 (4th Cir.) (corporation can be convicted even if it was actually harmed by an illegal act that an employee believed to be in corporation's interests, actual benefit being "evidential, not . . . operative"), cert. denied, 326 U.S. 734 (1945). For a review of this line of cases, see Commonwealth v. Beneficial Finance Co., 360 Mass. 188, 253-94, 275 N.E.2d 33, 71-94 (1971), cert. denied, 407 U.S. 914 (1972).

33. New York Central, 212 U.S. at 494. The Conrt explained its decision as follows:

We see no valid objection in law, and every reason in public policy, why the corporation which profits by the transaction, and can only act through its agents and officers, shall be held punishable by fine because of the knowledge and intent of its agents to whom it has intrusted authority to act in the subject-matter of making and fixing rates of transportation, and whose knowledge and purposes may well be attributed to the corporation for which the agents act. While the law should have regard to the rights of all, and to those of corporations no less than to those of individuals, it cannot shut its eyes to the fact that the great majority of business transactions in modern times are conducted through these bodies, and particularly that interstate commerce is almost entirely in their hands, and to give them immunity from all punishment because of the old and exploded doctrine that a corporation cannot commit a crime would virtually take away the only means of effectually controlling the subject-matter and correcting the abuses aimed at.

Id. at $495-96$.

34. Developments in the Law-Corporate Crime: Regulating Corporate Behavior Through Criminal Sanctions, 92 HARv. L. REv. 1227, 1246-47 (1979) [hereinafter Regulating Corporate Behaviorl; Note, Decisionmaking Models and Corporate Crime, 85 YALE L.J. 1091, 1095-96 \& n.21 (1976) (authored by Simeon M. Kalesberg). See generally 10 W. FlETCHER, Cyclopedia Of THE LAW OF PRIVATE CoRPORAtIoNs $\S 4942$ (rev. perm. ed. 1986) (detailing respondeat superior requirements). 
the corporation, ${ }^{35}$ and unlike in the Model Penal Code, ${ }^{36}$ responsibility is not restricted to high managerial agents.

For crimes requiring knowledge, courts have found corporations guilty even though no single agent possessed enough information to know of any wrongdoing. For example, in United States v. T.I.M.E.D.C., Inc. ${ }^{37}$ the court held that a corporation knowingly violated ICC regulations based on the "collective knowledge" of the employees as a group. ${ }^{38}$ Thus, despite no single employee's having sufficient knowledge of the violation to be convicted himself, the corporation may nevertheless be found guilty. ${ }^{39}$

\section{B. "High Managerial Agent" Liability}

The second theory of corporate blameworthiness, embraced by the Model Penal Code, ${ }^{40}$ holds the corporation morally responsible only for its "high managerial agents," 41 but not for its lower level employees. This view sees "high corporate management [a]s the brain center of the corporation."42 Since these officials have the power to appoint and control, their actions reflect corporate pohicy. In contrast to the first theory of moral blameworthiness, which treats the corporation as conceptually distinct from its employees by emphasizing corporate vicarious liability for the acts of agents, the "high managerial agent" theory conceptually equates the corporation with its employees. The decisions of top management are identified as the einbodiment of corporate will ${ }^{43}$ rather than

35. See 10 W. FLetcher, supra note $34, \S 4942$, at 665 ; see also Standard Oil Co. v. United States, 307 F.2d 120, 127 (5th Cir. 1962) (criminal conduct by even the lowest-ranking employee, acting without any authorization, will bind the corporation if illegal acts are committed within scope of employment); Elkins, Corporations and the Criminal Law: An Uneasy Alliance, 65 KY. L.J. 73, 106 (1976) ("The general rule now established in the federal courts is that the status of the actor within the corporate hierarchy is not determinative of whether the individual may bring criminal sanctions upon the corporation ....".).

36. See infra text accompanying notes $40-45$.

37. 381 F. Supp. 730 (W.D. Va. 1974).

38. Id. at 738 .

39. Id. at 741; see also American Medical Ass'n v. United States, 130 F.2d 233, 253 (D.C. Cir. 1942) (conviction of a medical association does not depend upon the guilt or innocence of its agents), aff'd on other grounds, 317 U.S. 519 (1943); United States v. General Motors Corp., 121 F.2d 376, 411 (7th Cir.) (acquittal of officers and agents, even though they were the only persons through whom the corporations could have acted, should not operate to set aside verdict against corporations), cert. denied, 314 U.S. 618 (1941).

40. Specifically, the second theory of corporate blameworthiness is embodied in Model Penal Code $\S 2.07(1)(c)(1985)$, which governs the "general liability of corporations for crimes defined by the criminal code." Id. comment at 335 .

41. A "high managerial agent" is defined as "an officer of a corporation . . . or any other agent of a corporation ... having duties of such responsibility that his conduct may fairly be assumed to represent the policy of the corporation." Id. $\$ 2.07(4)(c)(1985)$.

42. Mueller, supra note 28 , at 47 .

43. See MODEL PENAL CODE $\S 2.07(4)(c)$ (1985) (conduct of "high managerial agent" equated with policy of corporation). 
as the individual decisions of agents working within an independently existing corporate form.

Many state legislatures have adopted the view of the Model Penal Code. ${ }^{44}$ Under Model Penal Code section 2.07(1)(c), a corporation can be held criminally responsible for misdenteanors and felonies if "the commission of the offense was authorized, requested, commanded, performed or recklessly tolerated by the board of directors or by a high inanagerial agent acting in behalf of the corporation within the scope of his office or employinent."45

\section{Corporate "Personality" Liability}

The third theory of corporate blaneworthiness considers the corporate entity blameworthy when its procedures and practices engender or fail to prevent corporate criminal violations. This theory assumes that "[i]llegal conduct by a corporation is the consequence of corporate processes such as standard operating procedures and hierarchical decisionniaking." 46 Although this theory is not currently used as a basis for imputing corporate criminal liability, it is important for purposes of this Comment because it points to orgamizational dynamics that could have an inipact on witnesses at trial. ${ }^{47}$

\section{II}

\section{RELATING CoRPorate CoNVICTIONS to IMPEACHMENT}

To be relevant evidence, the prior corporate conviction must in some way reflect on the probability that corporate witnesses will tell the truth at trial. This requires that a link exist between the prior corporate conviction and the witness; this linkage can be either direct or indirect. Where the actions of the witness herself caused or contributed to the prior corporate conviction, direct linkage exists. Indirect linkage between the prior crime and the witness is more nebulous, based on the likely organizational dynamics that lead to corporate convictions.

44. "The great majority of the enacted and proposed recent legislative revisions with provisions for corporate criminality" are based on the position of agents in the corporate hierarchy. Id. $\$ 2.07$ commentary at 340; see also id. at 340 n.18 (listing jurisdictions adopting the Model Penal Code's approach to corporate criminal liability).

45. Id. $\S 2.07(1)(\mathrm{c})$.

46. Regulating Corporate Behavior, supra note 34, at 1243; see also Comment, Corporate Criminal Intent: Toward a Better Understanding of Corporate Misconduct, 78 CALIF. L. REv. 1287 (1990) (authored by Ann M. Foerschler) (proposing corporate liability where corporate policies can be considered to have intended to benefit the corporation from crime).

47. See infra notes $58-90$ and accompanying text (linking prior corporate convictions through corporate personality). 


\section{A. "Direct Link" Impeachment}

The easiest case for the use of prior corporate convictions to impeach is when the corporate witness himself was convicted for behavior which led to the corporate conviction. "Under existing law, both the corporation and its responsible agents can be convicted for the same offense; corporate and individual criminal hability are complementary, not inutually exclusive." 48 Thus, for the same reasons that previous individual convictions are deemed relevant for impeachment purposes, where both the corporate witness and corporate entity have previously been convicted for the same behavior, ${ }^{49}$ it seems appropriate to allow the witness' impeachment with the corporate conviction. ${ }^{50}$

Even when the witness is not individually convicted, a direct link between the prior corporate conviction and the witness can exist. "A number of appellate opinions reveal situations in which juries have held the corporate defendant criminally hable while acquitting the obviously guilty agents who committed the criminal acts." 51 This evidence shows that an "obviously guilty agent" will not necessarily be convicted individually. ${ }^{52}$ In these cases, even though an individual is not convicted for the illegal acts for which she was clearly responsible, the requisite direct connection still exists between the previous corporate illegality and the witness. Therefore, the court should be able to admit evidence of these wrongful acts to impeach the witness at trial..$^{53}$

48. Regulating Corporate Behavior, supra note 34, at 1244.

49. Note that in the context of large-scale, public corporations, there is less likelihood that the person responsible for the previous conviction will be a subsequent witness. This may vary depending on where the individual responsible for the previous corporate liability is located in the corporate hierarchy. Presunnably, higher-level employees participate in more of the corporation's activities and will, therefore, be more likely to have been directly involved in the previous criminal behavior. Further, it is also more likely that these individuals will be called as witnesses by the corporation since they help inake corporate policy.

50. This result, however, seems somewhat superfluous in that the individual conviction itself can be used to impeach.

51. Model PENAL CODE $\S 2.07$ commentary at 337 (1985). Here, I discuss only the situation where an individual is not convicted because a jury chooses to acquit her even though she is "obviously guilty." However, under the collective knowledge model of corporate criminal liability, see supra notes 37-39 and accompanying text, an individual whose actions contributed to the prior corporate wrongdoing can nevertheless be innocent of the substantive crime for which the corporation was convicted. In this situation, the individual could not be directly linked to the prior corporate crime.

52. This result is inconsistent with the theory of respondeat superior, see Pevely Dairy Co. v. United States, 178 F.2d 363, 370-71 (8th Cir. 1949) (conviction of corporate defendants and acquittal of individual defendants "stripped the verdict ... of all semblance of logic"), cert. denied, 339 U.S. 942 (1950), and presumably reflects the belief that the corporate entity, as distinct from the individuals within it, is in part to blame for the criminal behavior of its agents. See Comment, supra note 46 , at $1302-03$.

53. This "obviously guilty agent" situation falls through the cracks of Rule 609 and Rule 608 . Rule 608 allows impeachment based on prior bad acts not amounting to convictions, see FED. R. EviD. 608(b), and the current language of Rule 609 does not consider this unique corporate 


\section{B. "Indirect Link" Impeachment}

In addition to direct link impeachment, the organizational dynamics of a corporation operating at the time of the corporation's prior conviction may allow indirect impeachment. There are two ways to establish the indirect colmection between the prior crime and witness. First, where the prior crime reflects corporate policy rather than individual action, corporate pohcymakers may be linked indirectly to the prior crime. Second, corporations have relatively enduring personalities which may link the prior crime to the corporate witness.

\section{Linking Prior Corporate Convictions to Policymakers}

Indirect linkage of corporate pohicyinakers to a prior crime differs froin direct linkage in that it is based on presumption rather than direct evidence. $^{54}$ That is, if the prior crime involves corporate policy, it is legitimate to impeach corporate policyinakers based on the presumption that they either acquiesced in or authorized the behavior leading to the prior crime. This presumption depends on the manager's position in the corporate hierarchy, and on the relationship of her position to the crime committed. ${ }^{55}$

A court can differentiate between crimes reflecting individual action and crimes reflecting corporate policy in two ways. The first is to examine the underlymg facts of the previous corporate conviction. ${ }^{56}$ Given the facts of a crime, a court would consider the likelihood that a particular policymaker was involved in it. The second way to differentiate is to presume mvolvement based on the type of crime previously committed. For example, Sherman Act violations generally involve

criminality situation. See infra note 109 and accompanying text (Rule 609 requires a prior individual conviction to impeach a witness). That neither rule addresses the "obviously guilty agent" situation results from the failure of the drafters of the Federal Rules of Evidence to contemplate the use of prior corporate convictions to impeach.

Procedurally, a court can listen to counsel's offer of evidence in order to establish the witness' role in the prior illegality. This offer should be circumscribed so as not to become too collateral to the issues at hand. See FED. R. EvID. 403 (although relevant, collateral evidence may be excluded).

54. Such presumptions are an important way of ascribing responsibility to persons within a corporation, given the difficulty in finding direct evidence of their involvement. See Silets \& Brenner, The Demise of Rehabilitation: Sentencing Reform and the Sanctioning of Organizational Criminality, 13 AM. J. CRIM. L. 329, 353 (1986) (noting "difficulty of identifying those individuals who were actually responsible for the commission of the [corporate] offense").

55. See United States v. Hilton Hotels Corp., 467 F.2d 1000, 1006 (9th Cir. 1972) (justifying conviction of corporation for antitrust violation on grounds that high management is "likely to have participated" in violation or was at least aware of violation), cert. denied, 409 U.S. 1125 (1973); see also United States v. Park, 421 U.S. 658, 670 (1975) (individual criminal liability can be imposed "not only to those corporate agents who themselves committed the criminal act, but also to those who by virtue of their managerial positions or other similar relation to the actor could be deemed responsible for its commission") (emphasis added).

56. See supra note 19 and accompanying text. 
corporate policymakers. Thus, when the prior conviction is a Sherman Act violation, a court can presume that certain of the corporation's policymakers were involved. ${ }^{57}$

Indirect link impeachment of corporate policymakers, then, is inappropriate where the prior crime reflects more the wrongdoing of individuals than of corporate policy. But, where the prior crime implicates corporate policy, it may be appropriate to impeach those individuals responsible for making the policy.

\section{Linking Prior Corporate Convictions Through Corporate Personality}

Although the personality theory of corporate blameworthiness ${ }^{58}$ has not been accepted as a valid method of imposing criminal liability, it points to an additional basis for allowing impeachment of a corporate witness who caimot be linked directly to the previous corporate illegality. If corporate personality exists and is stable over time, the connection between the previous conviction and corporate witness derives from the fact that the same corporate personality that led to the prior conviction will contimue to influence the witness at trial. Thus, corporate personality provides a second (and broader) ${ }^{59}$ rationale for impeaching a corporate witness with prior corporate convictions. In this Part, I will argue that a corporation does im fact have a stable personality that consistently influences its employees' behavior.

\section{a. Corporate Personality-Defining the Concept}

At all levels of the corporation there may be an institutionalization of irresponsibility that permits the corporation to function as if encumbered by blinders and may allow individuals in the corporation to remain largely unaccountable, often legally so as well as morally. Under these conditions, almost any type of corporate criminality ... is possible. ${ }^{60}$

Recognizing that " $[t]$ he illegal acts of persons are facilitated if not

57. See Hilton Hotels, $467 \mathrm{~F} .2 \mathrm{~d}$ at 1006 ("[I]t is generally true that high management officials, for whose conduct the corporate directors and stockholders are the most clearly responsible, are likely to have participated in the policy decisions underlying Sherman Act violations, or at least to have become aware of them.").

58. See supra notes $46-47$ and accompanying text.

59. The personality theory of corporate blameworthiness encompasses more than either the respondeat superior or Model Penal Code theories because it includes prior behavior that does not mect the "intent to benefit" or "scope of employment" elements of criminal liability under the latter two theories. Further, given that a corporate personality exists, it does not matter what the connection is between the corporate witness and the individuals responsible for the prior illegality: regardless of the connection, the same personality in effect at the time of the conviction is in effect at the time of the witness' testimony. In fact, unlike under the respondeat superior and Model Penal Code theories, under the personality theory the corporate witness does not even have to be employed by the corporation at the time of the previous illegality to permit impeachment based on the influence of corporate personality.

60. M. Clinard \& P. Ylager, Corporate Crime 44 (1980). 
altogether engendered by deviant organizational systems,"61 commentators have identified a number of organizational factors that lead to corporate crime. $^{62}$ The combination of these factors is what this Comment refers to as "personality."63

Commentators have argued that large organizational size, and the resulting corporate structure, is positively correlated with the frequency of criminal violations. ${ }^{64}$ As organizations get larger, specialized subunits develop interually, and, where organizations are geographically dispersed, subumits develop in different locations. As a result, corporations nuust delegate decisionmaking and develop operatimg procedures to accommodate the special needs of the different units and locations. ${ }^{65}$ As corporations get larger and niore complex, greater need for specialists or professionals arises. ${ }^{66}$ And, as a task or umit beconies more specialized, managers without detailed knowledge nuust defer to the specialist. Thus, specialization can impede oversight by managers, engendering illegal behavior. "These factors-size, delegation, and specialization-conibine to produce an organizational climate that allows the abdication of a degree of personal responsibility for almost every type of decision, from the inost inconsequential to one that niay have a great inupact on the lives of thousands." 67

The pursuit of profits can also lead to corporate wrongdoing, ${ }^{68}$ especially if the corporation is in a highly competitive industry. ${ }^{69} \mathrm{~A}$

61. Corporate and Governmental Deviance: Problems of Organizationai Behavior IN CONTEMPORARY Society 31 (M. Ermann \& R. Lundman eds. 1978).

62. See M. ClinARD \& P. YeAGER, supra note 60, at 43-67 (discussing factors leading to corporate crime); D. VaughaN, Controlling UNLawful ORganizational Behavior: Social Structure AND CoRPORATE Misconduct 67-87 (1983) (same). This discussion is primarily focused on large, publicly held corporations. "The immensity, the diffusion of responsibility, and the hierarchical structure of large corporations foster conditions conducive to organizational deviance." M. ClinARD \& P. YEAGER, supra note 60, at 43. For smaller corporations, it is more likely that the corporate witness either knew of, or was a direct participant in, the previous illegality. Thus, the rationale behind impeachment based on direct linkage would most likely apply.

63. Much of the following discussion comes from M. ClinaRd \& P. Yeager, supra note 60.

64. See id. at 44-46; NATIONAL INSTITUTE OF LAW ENFORCEMENT AND CRIMINAL JUSTICE, Illegal CoRporate Behavior 154 (M. Clinard ed. 1979) [hereinafter Illegal CoRporate BEHAVIOR].

65. M. Clinard \& P. Yeager, supra note 60 , at 44.

66. Id.

67. Id.

68. Id. at 47 ("[T] he desire to increase or maintain current profits is the critical factor in a wide range of corporate deviance, from refusal to install pollution control equipment to well-planned decisions to make a shoddy product that will wear out and need to be replaced.").

69. See id. at 60 ("Corporate wrongdoing sometimes reflects the normative structure of a particular industry."); M. CuINARD, CORPORATE ETHICs AND CRIME 59 (1983) (citing competition and greed, type of industry, and unfair competitive practices as popular responses to the question why some corporations are more etlical than others). According to Professor Clinard's study, the top responses to the question why some corporations are more ethical than others were: (1) top 
corporation may engage in criminal behavior because of the advantageous or necessary use of illegal practices in order to remain coinpetitive. These practices may include releasing new products before they are safe, ${ }^{70}$ or allowing unsafe working conditions. ${ }^{71}$

A corporation may also encourage illegal behavior through its culture. Organizational culture is the "organizationwide, relatively enduring set of beliefs or cognitions that often become normative and play an important part in determining the perceptions and actions of einployees."72 Corporate culture is important to the success of the corporation because the corporation must indoctrinate employees to pursue corporate goals. Thus, corporations put their new managers through an initiation period designed to weaken their ties to external groups and norms while encouraging their dependence and attachinent to the corporation. ${ }^{73}$

By creating an environment where the ethical reference point is the successful pursuit of corporate goals, the corporation insulates employees from individual competing ethical standards. ${ }^{74}$ In this context, the corporation's environment may encourage or fail to deter criminal or deviant behavior. And once im place, an organizational culture is "relatively impervious to change or at least to planned change." 75

The influence of top inanagement on unethical and illegal corporate

management; (2) competition and greed; (3) type of industry; (4) cthical history of the corporation; (5) financial difficulties; (6) unfair competitive practices; (7) corporate culture. Id. at 53-70; see also Sonnenfeld \& Lawrence, Why Do Companies Succumb to Price Fixing?, HaRv. Bus. REV., Jul.-Aug. 1978 , at 145, 153 (listing "industry characteristics" that lead to price fixing).

70. M. ClinARd \& P. YEAGER, supra note 60 , at 47 ("[S]everal writers have examined how certain industries, for example, the drug and chemical industries, are characterized by severe competition and strong profit drives that are hinked to demands for continual development of new products. Under these conditions, the pressures to falsify test data, market new products before their full effects are known, or engage in unethical sales techniques can have disastrous results on human beings as well as on the environment.") (citations omitted).

71. Id. at 48 .

72. G. Wieland \& R. Ullrich, Organizations: Behavior, Design, and Change 259 (1976); see also H. GUNZ, CAREers AND CoRPORATE Cultures 6 (1989) (describing "managerial culture" as "the shared basic assumptions in the firm about what its purpose is and what constitute "proper' managerial activities").

73. Illegal Corporate Behavior, supra note 64, at 8; see also D. VAughan, supra note 62, at 68-73 (describing internal processes leading to acculturation of employees to corporate norms). As one commentator has noted,

most companies have elaborate education and training programs that speed up the process of socialization. Rewards and punishments also reinforce the corporate values. Longerterm employees interualize corporate culture, and pass it on to new ones. People develop loyalty to and affection for the company and its traditions. Occasionally, however, that perpetuates a narrow perspective and, in extreine cases, denial of obvious facts.

Corporate Culture and Change 60 (M. Berman ed. 1986).

74. One commentator explains corporate crime through the "differential association" hypothesis. He argues that corporate criminals, hike other criminals, learn their behavior in association with those who define it favorably, and in isolation from those who define it unfavorably. E. Sutherland, White Collar Crime 240 (1983).

75. G. WIELAND \& R. ULLRICH, supra note 72 , at 262. 
practices is an important cultural factor that encourages corporate illegalities and perpetuates itself over time. When asked why some corporations are more ethical than others, corporate managers answered "top management" the most frequently. ${ }^{76}$ These individuals are the bedrock of a deviant corporate culture.

A corporation's culture connects the prior corporate conviction to a corporate witness. The imdividuals who committed the prior illegal acts had undergone a systematic education in the values of the corporation. The witness on the stand who represents the corporation will have undergone the same systematic education. Thus, the same dynamics that permit impeachment of mdividuals with their own prior convictions-that they are less likely to tell the truth at trial-apply to the witness who is representing such a corporation as well. The witness is likely to identify with the corporate goals, as others like him had done when they committed previous illegal acts, and attempt to further those goals consciously or subconsciously by helping the corporation avoid hability.

\section{b. The Enduring Nature of Corporate Personality}

Corporate personality provides an independent basis for linking the corporate witness to the prior corporate conviction because corporate personality persists over time. It is hard to predict whether a corporation will maintain its size. However, it seems safe to assume that if a largescale organization is in business at all, it will mamtain a size that will require delegation and specialization to accomplish corporate goals. Further, corporations will clearly contmue to desire profits, and will thereby be susceptible to the dynamics of profit-seeking. Moreover, barring a change of busmess, a corporation will continue to be subject to the normative environment of its particular imdustry.

The corporate "culture" that ensures corporate success is also persistent. ${ }^{77}$ Top management is a very important element in creating a corporation's culture, ${ }^{78}$ and is itself influenced by a corporation's existing culture. ${ }^{79}$ At the highest levels of a corporation's hierarchy, pohicymakers tend to perpetuate the same attitudes and behefs about how the corporation should be run. ${ }^{80}$ Because top management has a contimuing

76. See supra note 69 .

77. See M. Clinard \& P. Yeager, supra note 60 , at 66 ("Like other social organizations, corporations have inherent socialization pressures that are passed on through the generations."); $G$. WIELAND \& R. UlLRICH, supra note 72, at 259 (describing organizational culture as "relatively enduring").

78. See supra note 76 and accompanying text.

79. See M. Clinard \& P. Yeager, supra note 60 , at 66 ("Executives are subject . . . to the same kinds of indoctrination into the corporate mind as are einployees at lower levels-through their associations with others who play similar roles, through their training and education, and through their isolation from potentially countervailing influences.").

80. See M. EISENBERG, CoRPORATIONS 209 (1988) (noting that both inside and outside 
influence on corporate policy, absent an influx of an independent top management due to a takeover or merger, those persons in a position to change the policies engendering illegal conduct will hold the same managerial attitudes as those who initially approved the deviant policy. Indeed, the original policymakers may remaim in office.

The stability of the corporation's personality is evidenced by its pattern of corporate recidivism. ${ }^{81}$ "[E]xamples can ... be given of corporations that have recurrently run afoul of the antitrust laws, others that have regularly been found guilty of fraudulent activities, and still others whose products or methods of production liave repeatedly brought prosecution on liealth and safety charges." 82 Large corporations are far more likely than small ones to cominit criminal violations, and cominit a disproportionate share of serious violations. ${ }^{83}$ Moreover, corporations in certam industries are more likely to violate the law and to do so repeatedly. ${ }^{84}$

\section{c. Conclusions Based on Corporate Personality}

Since the respondeat superior theory operates to convict a corporation only when its agents act with intention to benefit the corporation, ${ }^{85}$ and the Model Penal Code operates to convict only if policymakers are involved, ${ }^{86}$ one can argue that a corporation's personality is necessarily iniplicated by a prior corporate conviction. Furthermore, since the factors that inake up a corporation's personality are relatively stable, we can presume their influence on the behavior of witnesses at trial.

But the strength of the influence of corporate personality on a particular individual is unclear. For example, an action by an employee in defiance of a inanager's specific instructions will still bring liability to the corporation..$^{87}$ One could argue that no einployee of a corporation can

directors are economically or psychologically tied to incumbent management, or are likely to be aligned with incumbent management because the chief executive appoints and socializes new directors to the board).

81. When certain corporations are charged more than once with violations, it is possible, of course, that enforcement agencies, alerted to the possibility of repcat violations, have policed these particular firms more closely and thereby increased the odds that subsequent violations will be discovered. It is more likely, however, that some corporations . . . have developed a corporate atmosphere favorable to unethical and illegal behavior and that executives and other employees of these corporations may have become socialized to violate the law.

M. Clinard \& P. Yeager, supra note 60, at 117.

82. III StANDARDS For Criminal JUSTICE $18.168-69$ (2d ed. Supp. 1986).

83. M. Clinard \& P. Yeager, supra note 60, at 119.

84. See id. at 119-22 (oil, pharmaceutical, and motor vehicle industries most likely to violate the law with several firms having more than 21 violations each); see also supra notes 68-71 and accompanying text.

85. See supra notes $27-39$ and accompanying text.

86. See supra notes $40-45$ and accompanying text.

87. See, e.g., United States v. Hilton Hotels Corp., 467 F.2d 1000, 1004 (9th Cir. 1972) ("“A] 
help but be influenced by the corporate personality. However, there are clearly cases-such as action in defiance of specific instructions-where such affect is so attenuated as to have no significant infiuence on either the corporate employee who is responsible for the corporation's initial conviction, or on the corporate witness at a subsequent trial.

There are also problems of proof in the analysis of a particular corporation's personality. The use of corporate convictions should not raise so inany collateral issues that their inipeachment value is outweighed by the resulting confusion and waste of tine. ${ }^{88}$ It is also very difficult to identify the parts of a corporation's personality to which one would poimt in order to prove inpeachinent value. A corporation's recidivisin rate is easy to ascertain and probably reflects the existence of organizational factors that have encouraged prior criminal behavior, and that will influence the corporate witness' testiniony at trial. However, use of such evidence runs counter to the idea that evidence of past crimes should only go to impeachment, and should not be used to prove present guilt. ${ }^{89}$

Because the collateral issues associated with proving corporate personality can overwhelm a conviction's inipeachment value, courts should prevent counsel from offering evidence of organizational dynainics. But a court should nevertheless recognize that the potential influence of personality on corporate witnesses weighs in favor of admitting a prior corporate conviction. This is particularly true when the witness is a highlevel policymaker. Although not always directly involved in the prior transgression, the top policymakers set up the organizational elements constituting corporate personality. ${ }^{90}$ Thus, courts should presume that the credibility of high-level officials at trial is directly undermined by the corporate personahity that led to the previous illegality.

corporation is liable for acts of its agents within the scope of their authority even when done against company orders."), cert. denied, 409 U.S. 1125 (1973).

88. See FED. R. EvID. 403 ("Although relevant, evidence may be excluded if its probative value is substantially outweighed by the danger of unfair prejudice, confusion of the issues, or misleading the jury, or by considerations of undue delay, waste of time, or needless presentation of cumulative evidence."). Although the Court in Green v. Bock Laundry Machine Co., 109 S. Ct. 1981 (1989), held that the more general provisions of Rule 403 did not apply in the face of the more specific provisions of Rule 609, id. at 1992-93, these provisions are more important in the context of corporate convictions. The danger of confusion of issues and undue delay is more pronounced in the context of admitting prior corporate convictions to impeach than in the context of admitting prior individual convictions. In the former context, a court must consider whether the prior corporate conviction can be linked to a witness-an mquiry that is not required with prior individual convictions.

89. See Fed. R. Evid. 404(a).

90. This idea is consistent with the Model Penal Code's theory of corporate hability, which equates corporate officers with corporate policy. See supra notes $40-45$ and accompanying text. 


\section{III}

\section{THE LANGUAGE AND INTERPRETATION OF Rule 609(a) As APPLIED TO CORPORATE CONVICTIONS}

If a prior corporate conviction can be linked to a corporate witness, the conviction can legitimately be used for impeacliment purposes in certain circumstances. However, the current modes of analyzing the use of prior convictions to impeach are limited to the use of prior individual convictions. In this Part, I will slow, using the language and interpretations of Federal Rule of Evidence 609(a), that state and federal evidentiary rules provide inadequate guidelines for courts deciding whether to allow previous corporate convictions to impeacl witnesses. In fact, the literal language of Rule 609(a) precludes the use of corporate convictions to impeacl altogether. Also in this Part, I suggest that the admissibility of such evidence sliould always remam in the sound discretion of the trial court. This suggestion runs counter to the present practice because neither Rule 609(a)(1) (as interpreted in Green ${ }^{91}$ ) nor 609(a)(2) accommodates the necessity of discretion in the trial court when counsel attempts to use prior corporate convictions to impeach witnesses.

\section{A. Corporate Felonies}

Rule 609(a)(1) regulates the use of prior felonies to impeach in federal court. However, by defining felonies as only those crimes punishable by "deatl or imprisonment," iment to using previous corporate felony convictions to impeach. Yet, these more "serious" crimes are precisely the types of organizational crimes providing the strongest case for impeachment. ${ }^{93}$ Although historically corporations could not be convicted of felonies (because they were defined only by the punishment of "deatli or imprisonment"), ${ }^{94}$ more and

91. See supra notes $13-14$ and accompanying text.

92. FED. R. Evid. 609(a)(1).

93. See infra notes 96-108 and accompanying text.

94. See $10 \mathrm{~W}$. FleTCHER, supra note 34, § 4946, at 679 ("Even if it be conceded that a corporation has the capacity to commit a particular crime, it cannot be indicted if the punishment prescribed for the crime cannot be imposed upon a corporation. A corporation, therefore, cannot be indicted for a felony, where the only punishment provided is death or imprisonment, since a corporation cannot be subject to either penalty ....") (citations omitted); see also Annotation, Corporation's Liability to Criminal Prosecution As Affected By Punishment or Penalty Imposed, 80 A.L.R.3d 1220, 1223 (1977) ("The rule is well settled that a corporation is not amenable to prosecution for a criminal offense which is not punishable otherwise than by death or by imprisonment."). However, when a statute's prescribed punishment does not depend on corporeal existence, courts have held corporations crininally liable. Thus, where the punishment provided is a fine only, courts have found the criminal prosecution of corporations appropriate. Id. at 1222-23. Similarly, most courts allow prosecution of corporations where the penalty provided for a criminal offense is a fine and imprisonment, id. at 1225 , and where the penalty provided is a fine or imprisonment or both. Id. at 1227 . So long as it is possible to impose a non-corporeal penalty on the corporation, courts have found corporations criminally hable. See 2 F. BAILEY \& H. 
more legislatures are making special penalty provisions for corporate felony convictions. ${ }^{95}$ Thus, courts now more frequently convict corporations of felonies. The language of 609 (a)(1), however, still commands that courts admit only evidence of those previous crimes that have "death or imprisonment" as a punishment for impeachment purposes. This effectively bars the use of corporate convictions to impeach future witnesses.

The Pinto case ${ }^{96}$ illustrates how Rule 609(a)(1) has lagged behind expanding notions of state corporate criminal hability for "serious" offenses. Despite the expansion of corporate criminal hability, no corporation has ever been convicted of any homicide offense requiring "intent or malus animus." However, Ford Motor Co. laid the foundation for expanding corporate hability in this direction. The Ford Motor Company went on trial for reckless homicide, rather than negligent homicide, following the deaths of three young women who were killed when their 1973 Pinto exploded into flames after being struck froin the rear by another vehicle. The state alleged that Ford had desigued and manufactured Pintos knowing that rear-end collisions could easily rupture the fuel systein (causing the car to explode), and had failed to correct the fuel system or to warn car owners of the danger. ${ }^{97}$

Ford argued that a corporation could not be indicted for reckless homicide under the Indiana Criminal Code. ${ }^{98}$ However, the Indiana Code supports potential criminal liability for corporations because it defines "person" to include corporations. 99 The Indiana Code further states that corporations are subject to prosecution for any offense, ${ }^{100}$ and that fines, costs, or forfeiture can be levied against a corporation convicted of any offense. ${ }^{101}$ Thus, the Indiana legislature had paved the way for Ford's conviction. While the jury ultimately acquitted Ford on the reckless honicide counts, ${ }^{102}$ Ford Motor Co. demonstrates that legisla-

Rothblatt, Defending Business and White Collar Crimes: Federal and State § 24:7, at 124 (2d ed. 1984) ("If the penal statute prescribes two independent penalties, it is construed as imposing them as far as possible. If one is impossible, the defendant may be subject to the other which is possible.") (citations omitted).

95. See, eg., TEX. Bus. CoRp. ACT ANN. art. 7.01, § F (Vernon 1980) (involuntary dissolution); id. art. 8.16, $\S \mathrm{F}$ (revocation of corporate charter for foreign corporations).

96. State v. Ford Motor Co., No. 5234 (Ind. Super. Ct. Feb. 2, 1979), 47 U.S.L.W. 2514 (1979). For a discussion of the case, sec M. ClinARD \& P. YEAGER, supra note 60, at 260-62; Comment, Corporate Criminal Liability for Homicide: Can the Criminal Law Control Corporate Behavior?, 38 Sw. L.J. 1275, 1281-82 (1985) (authored by John E. Stones).

97. See 47 U.S.L.W. at 2515; see also Comment, supra note 96, at 1281.

98. See 47 U.S.L.W. at 2515; M. CliNARD \& P. YEAGER, supra note 60, at 260-62; see also Comment, supra note 96 , at 1281.

99. IND. CODE ANN. § 35-41-1-2 (West 1978).

100. Id. § 35-41-2-3(a).

101. Id. $\S 35-41-2-3(\mathrm{~b})$.

102. See M. ClinARD \& P. YeAGer, supra note 60, at 261; Comment, supra note 96, at 1282. 
tures and courts are together expanding corporate criminal liability to include offenses for which corporations previously have not been prosecuted. ${ }^{103}$

There is reason to believe that corporate liability for felonies will continue to expand. First, as in Indiana, the trend in other states is to create special penalty provisions for corporations. ${ }^{104}$ Second, the expansion of corporate hability in other areas will make it easier for courts to interpret statutes prescribing only corporeal punishments as exemplifying legislative omission rather than legislative intent not to punish corporations. ${ }^{105}$ Third, the mability of a corporation to suffer the prescribed pumishment is usually used by courts as a supplementary, not determinative, basis for refusing to find corporations criminally hable. ${ }^{106}$ As the conceptual barriers are removed by the developing law, courts will likely use this "hook" less frequently in the future. Fourth, the two doctrines under which corporations are convicted, respondeat superior and officer responsibility, somewhat bridge the conceptual barrier to corporeal punishment in that the corporate einployee whose actions brought criminal liability does have bodily existence. ${ }^{107}$

This expansion of corporate hability to cover those crimes having the greatest mipeachment value at subsequent trials renders the current language of Rule 609(a)(1) insufficient to govern the adinissibility of evidence of prior corporate convictions. Crimes with probative value as impeachment evidence are no longer limited to those that have "death or imprisonment" as a punishment. ${ }^{108}$

103. In addition to laying the foundation for attributing mens rea to corporations for corporate homicide, Ford Motor Co. also marked the first time that a corporation faced criminal liability for a product safety violation. See M. ClinARD \& P. YEAGER, supra note 60, at 261; Comment, supra note 96 , at 1281 .

104. See, e.g., Model Penal Code $\$ 6.04$ commentary at 71 (special penalty provisions for corporations convicted of crime).

105. Courts have at times interpreted the prescribed penalty for a crime as indicating legislative intent to include or not to include corporations as potential perpetrators of the crime. See State v. Pacific Powder Co., 226 Or. 502, 507, 360 P.2d 530, 532 (1961) ("No doubt should lie in anyone's mind that the legislature ever considered making corporate entities criminally liable for murder, for the only penalties provided are either death or imprisonment, penalties incapable of execution in the manner prescribed by law."). But see United States v. Van Schaick, 134 F. 592, 602 (C.C.S.D.N.Y. 1904) (stating that omission of appropriate punishment in manslaughter statute indicative of legislative oversight, not intention to preclude application to corporations). See generally Annotation, supra note 94 (corporation not amenable to prosecution for criminal offense punishable only by death or imprisonment).

106. See Comment, Corporate Homicide: The Stark Realities of Artificial Beings and Legal Fictions, 8 PePperdine L. Rev. 367, 399 (1981) (authored by Douglas S. Anderson).

107. See id. at 399-400 ("[T]he trend is to recognize the agent's and officer's ability to suffer the penalty on behalf of the corporation that employs them by way of a vicarious criminal liability.") (citations omitted).

108. Arguably, the language of Rule 609 can be broadly construed in the same way some courts have broadly construed state criminal codes in order to impose corporate liability. However, changing the language to apply facially to corporate convictions to impeach would better satisfy 


\section{B. Corporate "Witnesses"}

By its plain language, Rule 609(a) applies only when the witness himself lias been convicted of a crime. ${ }^{109}$ Since the corporate entity is a legal fiction and witliout corporeal existence, it cannot be a witness at trial. Only the individuals who comprise the corporation can testify. Therefore, prior corporate convictions can never be used to impeacli under 609(a), because the corporation, not the witness on the stand, will be the one witli a previous conviction. Tlrus, the current language of 609(a) prevents the jury from hearing important evidence that would better allow it to assess the credibility of a corporate witness.

\section{Discretion}

As written, Rule 609(a)(1) permits a court to admit evidence of prior felonies to impeach a witness at trial where it deternnines that "the probative value of admitting this evidence outweighs its prejudicial effect to the defendant." 110 The Green Court interpreted the negative implication of this language as requiring a court to admit such evidence to inpeach any witness in a civil trial, and to inpeach prosecution witnesses in a criminal trial. ${ }^{111}$

The Court's rationale in Green can be applied ineaningfully only to prior individual convictions. In both criminal and civil trials, situations may arise where a prior corporate conviction cannot be linked to a witness at trial, and would therefore be inadmissible because irrelevant. ${ }^{12}$ Furthernore, Congress did not consider the use of prior corporate convictions when writing 609(a)(1). Tlus, the Court's reading of Rule 609(a)(1) should not be transplanted into the context of corporate convictions.

Rule 609(a)(2) poses the same problem: It does not give a court any discretion to exclude previous convictions involving "dishonesty or false statement." ${ }^{113}$ However, many corporate crimes involving these issues ${ }^{114}$ should not be used for impeachment purposes because they lack a sufficiently close connection between the previous crime and the corporate witness. Thus, a court should have discretion under 609(a)(2) as well as under 609(a)(1).

notions of legislative supremacy, would make it easier for courts to allow such convictions, and would provide more judicial consistency in admitting such convictions.

109. FED. R. Evid. 609(a).

110. Id.

111. See supra notes 13-14 and accompanying text.

112. FED. R. Evid. 402 (irrelevant evidence is inadmissible).

113. Id. 609(a)(2).

114. See, e.g., sources cited supra note 20 (examples of statutes involving such crimes). 


\section{IV}

\section{Post-ReleVance: Discretionary Factors to Consider in Admitting Prior Corporate Convictions}

Whether a connection exists between the previous illegality and the witness at trial is an issue unique to the use of corporate convietions to impeach. The mere existence of such a connection, however, does not end the admissibility inquiry. As with the inquiry for prior individual convictions, a court should consider a variety of factors in deciding whether to admit a previous corporate conviction. Factors that would generally be relevant to the inquiry include: (1) the nature of the prior crime; (2) the recency or reinoteness in time of the prior conviction; (3) the similarity of the prior crime to the present crime; (4) the importance of defendant's testimony; and (5) the importance of credibility to the issues at trial. ${ }^{115}$ The considerations underlying soine of these factors differ between individual and corporate convictions.

\section{A. Nature of the Prior Crime}

As it does when using prior individual convictions, a court using prior corporate convictions to impeach individuals at a subsequent trial must determine whether the previous critne is probative of the credibility of a witness. Both individuals and corporations can be convicted of crimes that impugn the credibility of those connected with such crimes. ${ }^{116}$ Thus, as to this factor, the inquiry is the saine for individual and corporate convictions.

\section{B. Recency or Remoteness of the Prior Conviction}

A conviction can becoine stale and lose its probative value over time. In the context of prior individual convictions, this issue arises in

115. These factors were suggested by Judge (later Chief Justice) Burger in Gordon v. United States, 383 F.2d 936, 940-41 (D.C. Cir. 1967), cert. denied, 390 U.S. 1029 (1968). Although Gordon was decided before the Federal Rules of Evidence were adopted, courts and commentators have considered these factors useful for the discretionary decision courts must make under Rule 609(a)(1). See, e.g., United States v. Givens, 767 F.2d 574, 579 n.2 (9th Cir.), cert. denied, 474 U.S. 953 (1985); United States v. Acosta, 763 F.2d 671, 695 n.30 (5th Cir.), cert. denied, 474 U.S. 863 (1985); United States v. Murray, 751 F.2d 1528, 1533 (9th Cir.), cert. denied, 474 U.S. 979 (1985); United States v. Grandmont, 680 F.2d 867, 872 n.4 (1st Cir. 1982); United States v. Hawley, 554 F.2d 50, 53 n.5 (2d Cir. 1977); United States v. Mahone, 537 F.2d 922, 929 (7th Cir.), cert. denied, 429 U.S. 1025 (1976); see also 3 D. LOUISELL \& C. MUELLER, supra note 9, § 316, at 327-32 (general diseussion of the five factors).

116. There has been a wide range of opinion whether particular kinds of previous crimes reflect on future credibility at trial. See Johnson v. United States, 424 F.2d 537, 537 (9th Cir. 1970) (felonies only); United States v. Griffin, 378 F.2d 445, 446 (6th Cir. 1967) (crimes involving moral turpitude only); United States v. Cohen, 177 F.2d 523, 525 (2d Cir. 1949) (allowing all convictions for impeachment purposes), cert. denied, 339 U.S. 914 (1950); H.R. REP. No. 650, 93d Cong., 1st Sess. 11 (1973) (crimes involving dishonesty or false statement only). 
the court's discretionary decision under Rule 609(a)(1) ${ }^{117}$ and in the application of Rule 609(b), ${ }^{118}$ which applies to convictions under both 609(a)(1) and 609(a)(2). The considerations that make it reasonable to exclude stale individual convictions also apply to corporate convictions, because corporate crime depends on the actions of individuals. The corporate personality model, however, may suggest a different conclusion. The relatively enduring nature of the organizational features of corporations ${ }^{119}$ implies that the same dynamics that led to the old crime will contimue to influence the witness, regardless of the time period between the conviction and the trial. Accordingly, a court may want to consider the staleness of a prior corporate conviction differently than it considers the staleness of a prior individual conviction.

Ultimately, the relevance of the staleness factor to a prior corporate crime will depend on the particular facts. Where a large, recidivist corporation is involved, the influence of a corporation's personality on its employees can be presumed, ${ }^{120}$ and staleness is less relevant. In other situations, the staleness inquiry should be similar for both individual and corporate convictions.

\section{Similarity of Prior Crime to Present Crime}

Prior corporate convictions may indicate that the corporation's organizational dynamics engender deviant conduct. A high recidivism rate most likely reflects the persistence of these dynamics. If the saine corporate personality that led to the previous illegality continues to affect the corporate witness at trial, the credibility of such a witness is as questionable as the credibility of a witness with prior individual convictions. Thus, similar past corporate crimes may be highly probative impeachment evidence.

When the prior crime is similar to the present charge, however, the jury may misuse the prior conviction. Rather than considering the prior crime for impeachment purposes, the jury may use it to infer the defendant's present guilt or to pumish the defendant because it believes that the

117. Since 609 (a)(2) does not allow discretion, recency is not relevant to its application. However, courts will consider recency under 609(a)(1). See United States v. Hawley, 554 F.2d 50, 53 (2d Cir. 1977) (court approves of trial court's consideration of recency of prior conviction under 609(a)(1) balancing test); United States v. Hayes, 553 F.2d 824, 828 (2d Cir.), cert. denied, 434 U.S. 867 (1977) (acknowledging that recent convictions have more probative value).

118. Evidence of a conviction under this rule is not admissible if a period of more than ten years has elapsed since the date of the conviction or of the release of the witness from the confinement imposed for that conviction, whichever is the later date, unless the court determines, in the interests of justice, that the probative value of the conviction supported by specific facts and circumstances substantially outweighs its prejudicial effect.

FED. R. EvID. 609(b).

119. See supra notes 77-84 and accompanying text.

120. See supra notes $60-90$ and accompanying text. 
defendant has a bad moral character. ${ }^{121}$ Courts have therefore been reluctant to admit similar prior crimes of an individual for impeachment purposes. ${ }^{122}$ While a jury inay not hold a corporation inorally accountable in the same way it does an individual, it nevertheless nay infer present guilt based on a past similar crime. Thus, courts should be wary of the "similar crime" factor in using corporate as well as individual convictions to impeach.

\section{Importance of the Defendant's Testimony}

When the individual defendant has a criminal record, "the adinissibihty of his prior convictions will significantly affect his decision whether or not to testify." 123 This reflects the fear that juries will inisuse such convictions to infer present guilt or to pumsh bad inoral character. ${ }^{124} \mathrm{~A}$ court should therefore consider whether it is "inore important that the jury have the benefit of the defendant's version of the case than to have the defendant reinam silent out of fear of iinpeachinent." 125

When the defendant is a corporation with a criminal record, the same dilemma arises with respect to witnesses friendly to the corporation. While the corporate entity cannot testify in its own behalf, it must still decide whether to send someone to testify, and it will make that decision by the saine calculus as an individual. Since a jury may still misuse the prior corporate conviction by inferring present guilt or punishing bad corporate "character," it may be in the corporation's best interest to avoid putting friendly witnesses on the stand. In this situation, the court will have to consider whether the potential value of such witnesses' testinnony outweighs the potential prejudice to the corporation.

When witnesses hostile to the corporation testify, it is unlikely that either the prosecution or the defendant-corporation will want to impeach thein. The prosecution will not want to impeach a witness that is helping

121. See 3 D. Lou1SEll \& C. Muellen, supra note 9, § 316, at 329; see also Betro, The Use of Prior Convictions to Impeach Criminal Defendants-Do the Risks Outweigh the Benefits?, 4 ANTIOCH L.J. 211, 218-23 (1986) (discussing the increased likelihood of conviction where prior convictions are admitted, and the inefficacy of giving limiting instructions to the jury).

122. As one court noted:

A special ... problem arises when the prior convietion is for the saine or substantially the same conduct for whicl the accused is on trial. Where multiple convictions of various kinds can be slown, strong reasons arise for excluding those which are for the samc crime because of the inevitable pressure on lay jurors to believe that "if he did it before he probably did so this time." As a general guide, those convictions which are for the same crime sliould be admitted sparingly ....

Gordon v. United States, 383 F.2d 936, 940 (D.C. Cir. 1967) (citations omittcd), cert. denied, 390 U.S. 1029 (1968).

123. 3 D. Louisell \& C. MUelleR, supra note $9, \S 316$, at 331 (citations omitted).

124. See supra notes 121-22 and accoinpanying text.

125. Gordon, 383 F.2d at $940-41$ (citations omitted). 
its case, and the corporation will not want to bring up its own previous convictions. Nevertheless, a court must be particularly careful whenever the prosecution does choose to use a prior corporate conviction to impeach a witness hostile to the corporation. A court must be aware that a prosecutor who atteinpts to bring in a prior corporate conviction may be attempting to capitalize on the tendency of jurors to use prior crimes to infer present guilt or bad character.

\section{E. Importance of Credibility Issues to Trial}

When a case turns on the credibility of conflictimg witnesses, courts are more likely to allow prior convictions to impeach. ${ }^{126}$ The rationale behind this practice is that where credibility is deternimative, the benefits derived from the impeachinent value of a prior conviction are more hikely to outweigh the risks associated with admitting prior convictions. This rationale apphies whether the prior conviction is individual or corporate.

In sum, after a court has decided a prior corporate conviction is relevant for purposes of impeachment, the court must consider whether the probative value of allowing such a conviction for impeachinent purposes outweighs its prejudicial affect. For the "Nature of the Prior Crime," "Similarity of the Prior Crime," and "Importance of Credibility Issues" factors, a court's inquiry will be similar for corporate and individual convictions. For the "Recency" and "Innportance of Defendant's Testimiony" factors, a court will have to consider the umique nature of corporate convictions when deciding whether admitting such convictions would be beneficial.

\section{$\mathrm{V}$}

\section{Proposal}

The relevance of the corporate conviction for mipeachment purposes depends on the connection between the prior illegality and the witness. Because there may be no such connection in a corporate conviction, the decision to admit prior corporate convictions should always be left to the discretion of the court. When the witness herself was convicted, the direct connection is sufficient to inpeach the witness whether or not she is a high managerial agent. Further, when the witness was an "obviously guilty agent" in the prior illegahty, ${ }^{127}$ she inay legitimately be inpeached by the prior corporate conviction.

In cases where the witness was not directly imvolved in the prior

126. See, e.g., Jones v. Collier, 762 F.2d 71, 72 n.2 (8th Cir. 1985) ("[Where] credibility of the witnesses is all important, the trial court will not abuse its discretion by admitting . . . evidence [of prior convictions].").

127. See supra notes 51-53 and accompanying text. 
illegality, the position of the witness in the corporate hierarchy becomes important. If the witness was an "officer, director, or managing agent" of the corporation at the time of the prior illegality, and the crime is of a kind that reflects corporate policy rather than an individual employee's acts, courts should presume that a connection exists between the witness and the prior illegality. This presumption is valid because these individuals are policymakers, and thus are most likely to be involved im policyrelated crimes. Furthermore, these pohicymakers establish the corporate personality that influences the employees' illegal behavior. The witness should be able to rebut this presumption witl evidence that she liad no part in the direct or indirect authorization of the prior wrongful act.

Once this connection is established-eitler through direct evidence or presumption-a court should consider the traditional "discretionary factors" that go to the merits of using a particular conviction for impeachment purposes im the context of a particular trial. This inquiry is similar, though not identical, for mdividual and corporate convictions.

Rule 609(a) and its state analogues do not reflect the unique considerations behind allowing prior corporate convictions to impeach. Yet, in certain situations, sucli convictions should be admitted at trial in order to further the truth-findimg mission of the courts. For this reason, I argue that a special evidentiary provision for corporate convictions should be enacted. The following language accommodates the special considerations a court should have in mind when deciding whether to admit prior corporate convictions to impeacli:

The decision to allow a prior corporate conviction to attack the credibility of a witness rests in the sound discretion of the court. The conviction, however, inust be relevant to the credibility of the witness. In addition, the probative value of admitting this evidence must outweigh its prejudicial effect. Felonies and crimes involving dishonesty or false statement, but not other crimes, should be considered by the court as having probative value.

This language is imtended to alleviate the current problems of applymg Rule 609(a) to corporate convictions. At the same time, it attempts to build on Rule 609(a)'s notion of when probative value outweighs prejudicial effect. The proposal's first noticeable departure from Rule 609(a) is that all of the trial court's decisions whether to admit prior corporate convictions are discretionary. The imquiry into relevance and probative value is far too fact-specific for compulsory admission rules.

The relevance requirement refers to the connection (established or presumed) that must be made between the witness and the previous corporate illegality. The language adopts Rule 609(a)'s view of which crimes are probative of credibitity. Untike Rule 609(a)(1), however, the word "felonies" is used, im place of language defining felonies only by 
their traditional punishment. Felonies committed by corporations thus can be admitted even though they are not punishable by death or imprisonment. Additionally, unlike Rule 609(a), the proposed language does not require that a witness be the person convicted. Thus, the language permits impeachment of witnesses who can be colmected to a prior corporate crimie.

\section{CONCLUSION}

Using corporate convictions to impeach witnesses at trial poses unique problems for courts. Unlike prior individual convictions, for prior corporate convictions, the witnesses may not be at all connected with the prior illegality. Thus, in assessing the impeachment value of a prior corporate conviction, a court nuust first determine whether it has any relevance at all. The connection between the prior corporate crinie and the witness that will establish relevance may be either direct or indirect. Direct linkage is when the witness was hiniself convicted or was an "obviously guilty" party in the prior illegality. Indirect linkage is when the cormection is established through a presumption based on the type of crime and witness involved and/or the corporation's personality.

Establishing the comiection between the prior corporate crime and the witness does not end a court's inquiry. It must then decide whether admitting the particular crime involved is on balance appropriate for the case at bar. This latter inquiry is similar though not identical for prior corporate and for individual convictions.

The language of Federal Rule of Evidence 609(a) is inadequate to accommodate this two-step process. Thus, this Comment argues for the adoption of, and gives a nrodel for, a special evidentiary rule to govern the use of such convictions. This new rule will further courts' truthseeking mission at trial by allowing for the presentation of probative evidence that courts have not heretofore carefully considered. 
